\title{
Influence of Mechanical Scarification and Open-Field Sowing Procedure over Cassia ferruginea Germination Process
}

\author{
Leonardo Regnier ${ }^{1, a *}$ \\ ${ }^{1}$ Institute of Biosciences, University of São Paulo, São Paulo, Brazil \\ ${ }^{2}$ Department of parks and green areas 2, Secretary of Green and Environment, São Paulo, Brazil \\ aregnier@alumni.usp.br
}

Keywords: Fabaceae, Seed dormancy, Seedling production, Canafístula.

\begin{abstract}
Seed dormancy implicates on delay and hampers seedling production. The increasing demand for greater seedlings production favors techniques that overcome seed dormancy. Cassia ferruginea is an economically relevant species that seeds present tegumentar dormancy, and there is no registry of the best sowing approach. In order to evaluate the influence of the mechanical scarification procedure, and open-field production method in the germination process of Cassia ferruginea, about five thousand seeds were evenly distributed between control and mechanical scarification with emery. The control group presented a low germination rate during the period of analysis. However, mean germination time and mean time to stabilize germination were remarkably lower to scarified seeds, also presenting higher germination rates and synchronization. The sporadic and low germination pattern observed in the control group is associated with ecological implications. The open-field production process presented significant differences to important indexes when compared to the greenhouse production process. Thus, mechanical scarification with emery is an appropriate method to overcome Cassia ferruginea seed dormancy, providing a faster, synchronized, and better seed lot exploitation. Favorable aspects of commercial seedling production. While the open-field production process was not adequate for seedling production.
\end{abstract}

\section{Introduction}

Cassia ferruginea Schrad ex DC species is popularly known as Tapira-coiana, or Canafistula-de-besouro, belongs to the Fabaceae and Caesalpinioideae subfamily. Presenting wide occurrence from northeast until the south region of Brazil [1]. This is an economically relevant species due to its ornamental use, to the detriment of its intense bloom [2]. Moreover, C. ferruginea is also employed in reforestation projects, and as a wood source on civil construction, ornaments, and matches [1].

One of the ecological and physiological strategies seeking germination on appropriate environmental conditions is seed dormancy [3]. Cassia genus presents dormancy associated with tegument impermeability, one of the most common dormancy types in Fabaceae [3,4]. Thereby, while seeds are under tegumentar dormancy, even if exposed to favorable conditions, the germination process is rarely induced. Only after wounds or disruption of the impermeable tegument, water permeability is possible, providing the beginning of the germination process [5].

Dormancy hinders commercial seedling production process, due to its unevenness and extended time required to germination [6]. The recent increasing demand for native species to reforestation and urban afforestation projects has been promoting a greater interest of techniques that could provide the production of healthier, higher quality and quantity of seedlings [7].

Processes to release dormancy have already been described for the Cassia genus [4] and also in Cassia ferruginea species [6]. Those authors concluded that chemical scarification with $\mathrm{H}_{2} \mathrm{SO}_{4}$ during 30 and 60 minutes, and mechanical scarification with sandpaper are the most efficient methods to overcome dormancy in seeds from Cassia genus.

Chemical scarification with acids compounds imposes some practical obstacles, as those compounds are expensive, very difficult to manage when a large number of seeds are submitted to this process, present the risk of accidents [6], or even generate wounds to seed embryonic tissues, 
which could result in abnormal seedlings [4]. Whereas mechanical scarification using emery is the most common alternative in the seedling production process because of its safety and low-cost [8]. Although this kind of approach has not been extensively studied.

Seedling production, in general, adopts two main processes, open-field germination, were seeds are directly exposed to the environmental conditions as sunlight and temperature; or germination at a greenhouse, where seeds are covered and protected, being exposed to lesser sunlight (due to greenhouse covering), but greater temperature and moisture than the open production area [9].

Thus, this study aimed to understand the influence of the mechanical scarification procedure, and open-field method in, the germination process of Cassia ferruginea Schrad ex DC in order to recognize the impact and perspectives of this procedure over seedling production.

\section{Materials and Methods}

This work was conducted in the Harry Blossfeld Municipal plant nursery of São Paulo, situated in the city of Cotia $\left(23^{\circ} 36^{\prime} 30.0^{\prime \prime} \mathrm{S} 46^{\circ} 50^{\prime} 48.9^{\prime \prime} \mathrm{W}\right)$. The climate is Cwa (altitude tropical climate) according to Köppen climatic classification [10]. Distinguished by rain concentrated during summer, and the highest mean temperature over $22^{\circ} \mathrm{C}$.

Plant material was collected in two different populations from Cotia and Aricanduva cities, at the end of April of 2018. Only fallen fruits were collected. This material was conserved in plastic bags at room temperature for 20 days, since processing.

The fruits were open manually. All the seeds were washed and only whole seeds were kept to the experiment. The final set of seeds consisted of five thousand one hundred and ten seeds evenly divided through two treatments with one repetition each. The first treatment, the control, seeds were directly planted in vermiculite. While the second treatment, seeds were submitted to Eletro Transol $(3550 \mathrm{rpm})$ emery scarification and then proceeded to sow. The scars were always inflicted in the opposite portion of the micropyle, until conspicuous tegument disruption. After that, the control and the scarified seeds were planted on white trays containing vermiculite, kept at the greenhouse with white plastic covering and fogging watering system with periodic activation every 35 minutes.

In order to evaluate the open-field procedure, three hundred and seventy scarified seeds were divided into 2 repetitions and sowed at plant beds also containing vermiculite as substrate, but without any kind of covering, and irrigation two times daily at 8 am and $4 \mathrm{pm}$. Plant emergence was recorded through 150 days after seeding, with measurements nearly every 7 days.

Mean germination time, mentioned by Czabator [11] as the mean length of incubation time [12], and standard deviation of all time measurements was calculated as proposed by Haberlandt in 1875 [13]. In which, the mean germination time is defined as:

$$
T_{m}=\frac{N_{g 1} T_{1}+N_{g 2} T_{2}+\cdots+N_{g n} T_{n}}{N_{g 1}+N_{g 2}+\cdots+N_{g n}}
$$

$T_{m}$ is the mean germination time, the measurement of the mean time required to one seed germination, or the average length of time required for maximum germination of a seed lot. The values: $N_{g 1}, N_{g 2}$ e $N_{g n}$ is the non-cumulative quantities of germinated seeds during specific times $T_{1}, T_{2}$ e $T_{n}$, respectively. And respectively standard deviation (s) noted as:

$$
s=\sqrt{\frac{N_{g 1}\left(T_{1}-T_{m}\right)^{2}+N_{g 2}\left(T_{2}-T_{m}\right)^{2}+\cdots+N_{g n}\left(T_{n}-T_{m}\right)^{2}}{\left(N_{g 1}-1\right)+\left(N_{g 2}-1\right)+\cdots+\left(N_{g n}-1\right)}}
$$

In this study, time was always presented in days. 
Mean time to stabilize germination $\left(T_{m e}\right)$, and its standard deviation, were calculated using the same rules for mean germination time, however, using cumulative germination data. Aiming to determinate the mean time required to germination and death rate reach the same amount, providing a stable seedling number on a seed lot.

Uncertainty index is associated with the distribution of the relative frequency of germination [14]. As presented in Ranal e Santana [12], and Lozano-Isla et al. [14], germination of a specific $\mathbf{k}$ time is described as:

$$
f_{k}=\frac{N_{g k}}{N_{g 1}+N_{g 2}+\cdots+N_{g n}}
$$

In addition, the Uncertainty index (U) is obtained:

$$
U=\left(-f_{1} \log _{2} f_{1}\right)+\left(-f_{2} \log _{2} f_{2}\right)+\cdots+\left(-f_{n} \log _{2} f_{n}\right)
$$

Germination speed and Synchronization indexes were calculated using GerminaQuant software, which is based on Lozano-Isla et al. [14] article. All data were compiled to the Excel component of Microsoft Corporation Office pack and represented through graphics and tables. Treatments indexes were obtained through the GerminatQuant tool [14] and represented using graphs. All the statistical tests were using Bioestat 5.0 software. The results were tested by ANOVA and in sequence submitted to the Tukey test with a critical $p$-value of $1 \%(\alpha \leq 0.01)$.

\section{Results}

\section{Scarification}

The time for the first germination expresses that the emergence of first seeds is equal for scarified and control treatments (Table 1), starting on the eleventh day after seeding $\left(\boldsymbol{t}_{0}=11\right)$, however, the time for $50 \%$ of germination is 15.93 days to scarified seeds. Time for $50 \%$ of germination of the control group could not be calculated due to its inconstant pattern of germination that not reaches $50 \%$, and preclude even this index estimation.

Mean germination time and Mean time to stabilize germination were significantly lower to seeds submitted to the scarification process. Standard deviation values show that the control group presented greater variations between the repetitions.

Table 1. Mean time, in days, for the first germination $\left(t_{0}\right)$, to reach $50 \%$ of germination $\left(t_{1 / 2}\right)$, to stabilize germination $\left(T_{m e}\right)$ and mean germination time $\left(T_{m}\right)$ to control and scarification procedure

\begin{tabular}{lcccc}
\hline Treatments & $t_{0}$ & $t_{1 / 2}$ & $T_{m} \pm \mathbf{s}$ & $T_{m e} \pm \mathbf{S}$ \\
\hline Control & 11 & $\ldots$ & $96.00 \pm 0.56$ & $128.69 \pm 44.8$ \\
& & & & $32.26 \pm 14.6^{*}$ \\
Scarification & 11 & 15.93 & $17.39 \pm 0.06^{*}$ & 3 \\
\hline
\end{tabular}

* Statistically significant difference $(p \leq 0.01)$.

The cumulative germination pattern was very different between the methods. The scarification process promoted faster germination and stabilization in a short time period (Fig. 1). While the control group presented very low germination during the first months, until a subtle rise in the last months of the experiment. Reaching stabilization during the last measurements. 


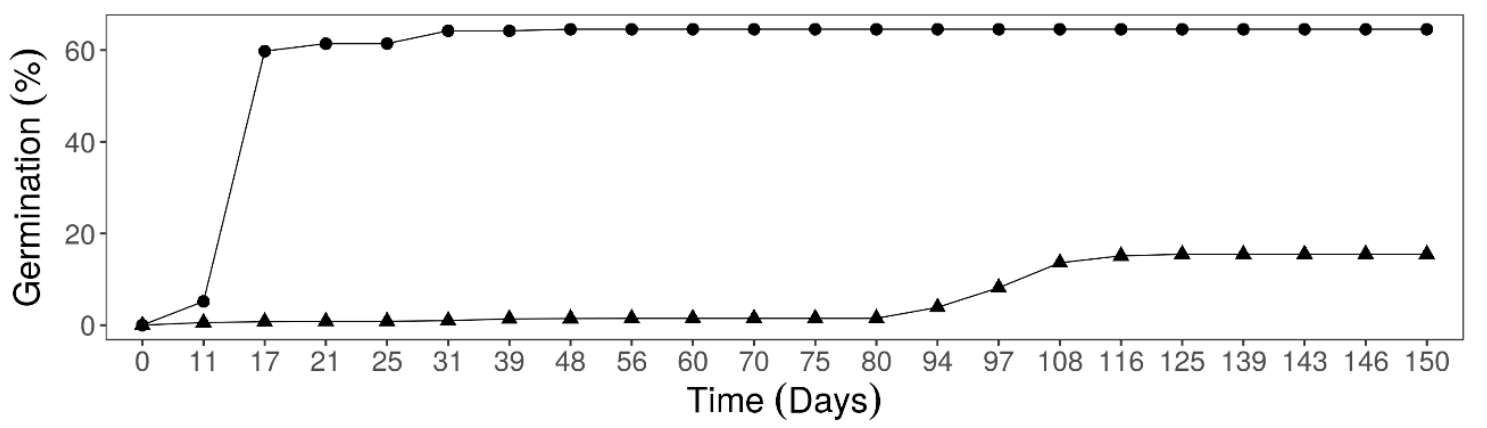

Figure 1. Cumulative germination of Cassia ferruginea seeds submitted to scarification $(\bullet)$ and control $(\mathbf{\Delta})$ treatments during 150 days of the experiment

The germination rates of the treatments, during the experiment period, are significantly different (Table 2). Scarified seeds presented a higher germination rate. Germination speed was significantly lower to control seeds. While uncertainty and synchrony indexes were not statistically different.

Table 2. Mean germination rate, Uncertainty (U) and Synchronization index (Z), and also germination speed obtained to control and scarification treatment during 150 days of the experiment

\begin{tabular}{lcccc}
\hline Indexes & $\begin{array}{c}\text { Germination } \\
\text { rate }[\%] \pm \mathbf{s}\end{array}$ & $\begin{array}{c}\text { Uncertainty index } \\
\text { [bit] }\end{array}$ & $\begin{array}{c}\text { Synchronization } \\
\text { index }\end{array}$ & $\begin{array}{c}\text { Germination } \\
\text { speed [\%] }\end{array}$ \\
\hline Control & $15.48 \pm 2.76$ & 2.27 & 0.25 & 1.04 \\
Scarification & $64.75 \pm 0.96^{*}$ & 0.86 & 0.72 & $5.75^{*}$ \\
\hline
\end{tabular}

* Statistically significant difference $(\mathrm{p} \leq \mathbf{0 . 0 1})$

Plant emergence of scarified seeds presented a concentrated emergence during the first twenty days of the experiment (Fig. 2). While in the control group, the emergence of seedlings presented a sporadic and spaced pattern, almost constant during the first months of the experiment, until a slight rise during the last month, followed by a reduction during the last two measurements.

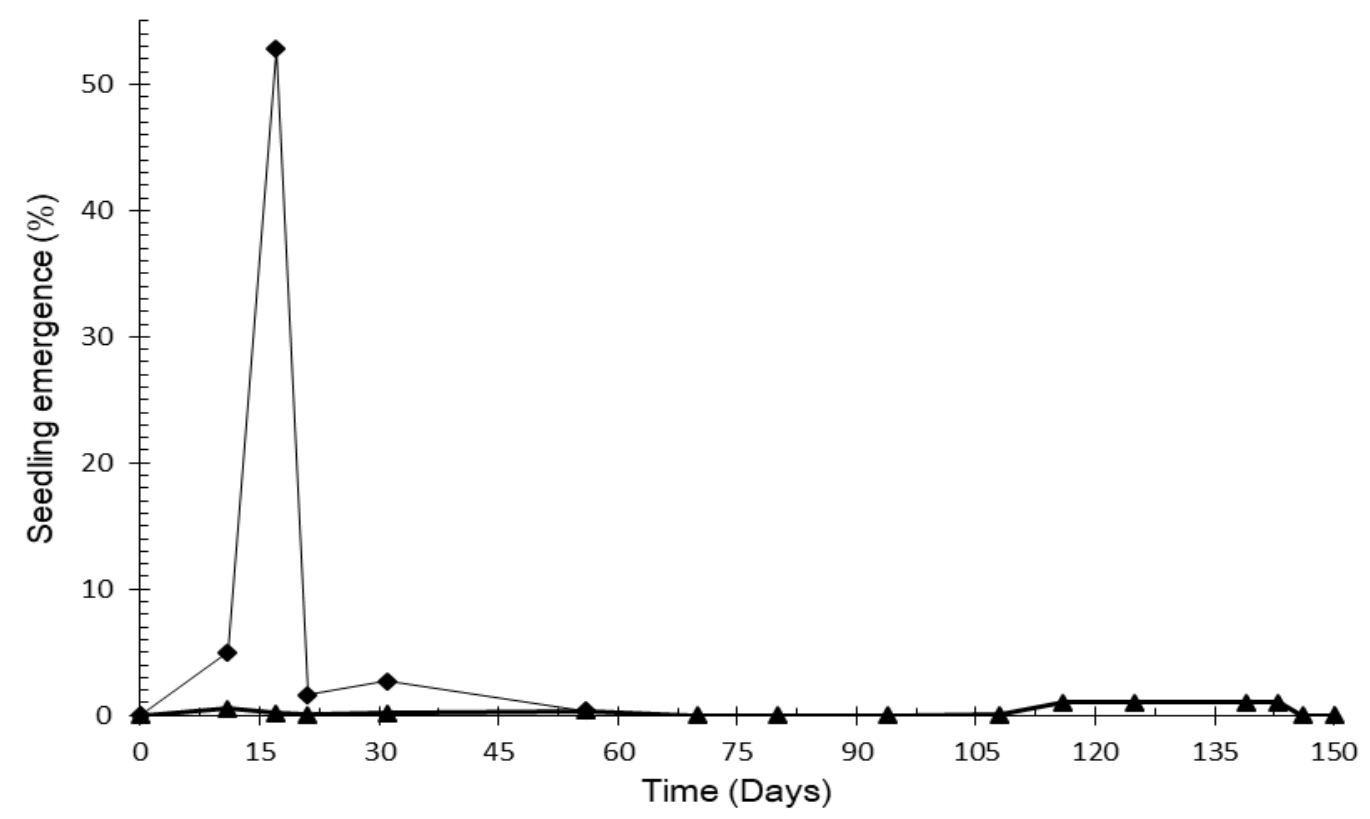

Figure 2. Non-cumulative emergence of Cassia ferruginea seeds submitted to scarification $(\diamond)$ and control $(\boldsymbol{\Delta})$ treatments during 150 days of experiment 


\section{Open-field vs greenhouse production methods}

Open-field presented an irregular pattern of germination when compared to greenhouse germination (Fig. 3). The time required to reach germination stabilization using the open-field production process was greater than the greenhouse method.

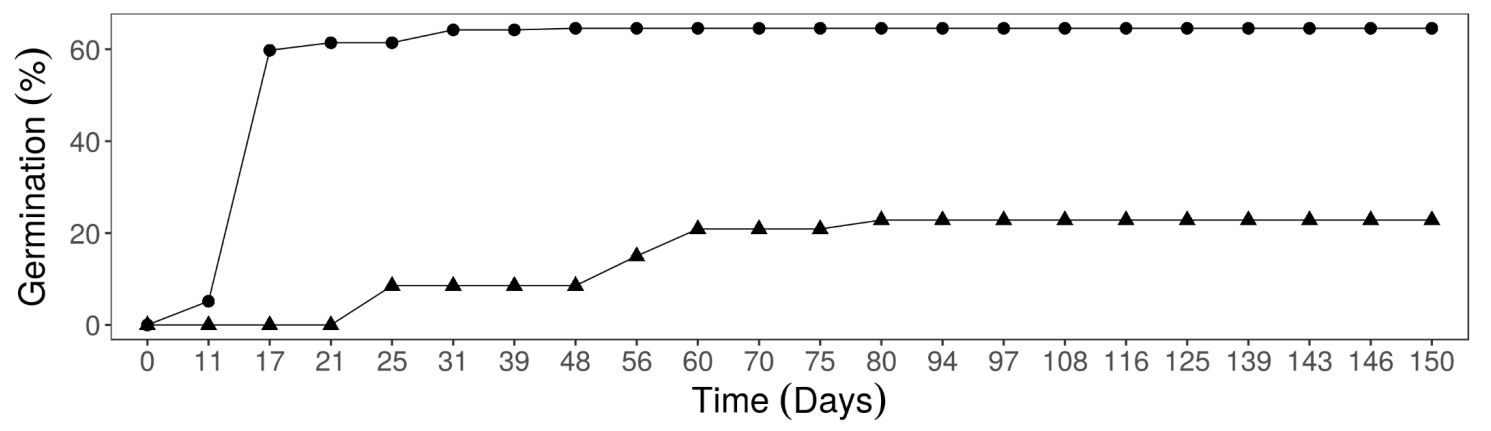

Figure 3. Cumulative germination of Cassia ferruginea seeds submitted to scarification and kept at the greenhouse $(\bullet)$ and open field $(\boldsymbol{\Delta})$ production process during 150 days of experiment

Germination indexes were different between the treatments (Table 3), but only germination rate, synchronization, and germination speed were significantly affected.

Table 3. Mean germination percentage, Uncertainty (U) and Synchronization index (Z), and also germination speed obtained to control and scarification process during 150 days of the experiment

\begin{tabular}{cccccc}
\hline Indexes & $\begin{array}{c}\text { Germination } \\
\text { rate (\%) }\end{array}$ & $\begin{array}{c}\text { Uncertainty } \\
\text { index (bit) }\end{array}$ & $\begin{array}{c}\text { Synchronization } \\
\text { index }\end{array}$ & $\begin{array}{c}\text { Germination } \\
\text { speed (\%) }\end{array}$ & $T_{m} \pm \mathbf{s}$ \\
\hline Greenhouse & $64.56 \pm 2.76$ & 0.86 & 0.724 & 5.75 & $17.39 \pm 0.06$ \\
Open field & $22.83 \pm 0.96^{*}$ & 1.18 & $0.283^{*}$ & $2.08^{*}$ & $48.54 \pm 6.87$ \\
\hline
\end{tabular}

* Statistically significant difference $(\mathbf{p} \leq \mathbf{0 . 0 1})$

\section{Discussion}

\section{Scarification}

Time for the first germination, which expresses the required time after seeding to the first seed germination, was equal to both treatments. Indicating that the scarification procedure does not affect the time required for the first emergences of $C$. ferruginea with great seed lots. In general, time for the first germination is not an accurate index to express time associated with the germination pattern [12], by the reason that it only informs the time required to first emergences evidently appear.

Time for $50 \%$ of germination $\left(t_{1 / 2}\right)$ index, as described by Ranal e Santana [12], presents the required time to reach half of the germination of a seed lot. Scarified seeds, require about 16 days $\left(t_{1 / 2}=15.92\right)$ after planting to reach half of the seed germination. The control group did not reach half of the germination, presenting a sporadic and inconstant pattern, usual pattern to dormant seeds without any treatment [6]. The time for $50 \%$ of germination and germination speed indexes indicates that scarified seeds have a faster response to favorable environmental conditions than seeds without treatment.

The rise and stabilization of seedling numbers are faster when seeds of $C$. ferruginea are scarified (Figure 1). This pattern strongly differs from the control group. Fifty-six days after planting, seedlings from the scarified method presented proper plant size for their transplantation in the adequate recipient. While control seedlings did not reach that adequate size until the last day of analysis and presented a very low germination rate. Similar effects, of faster stabilization and 
greater germination, have already been described to $C$. ferruginea when using chemical scarification $[4,6]$.

Mean germination time or mean length of germination time, demonstrates the required time to one seed of a species to germinate. It is an important index insofar as express the average length of time required for maximum germination of a seed lot [12]. Thereby, it is possible to estimate the necessary time for some specific culture to properly grow. Mean germination time of scarified seeds is about 17 days $\left(T_{m}=17.39\right)$, with almost no variation. Most of the emergence of the seedlings occurs in a short period (Fig. 2), between the eleventh and seventeenth days after seeding, which generates a low variation on the mean germination time index. Whereas the control group needed 96 days, approximately five and a half times the scarified seeds value. In addition, the control group presented a large range of variation due to the low and inconstant pattern of emergence, generating a higher uncertainty and low synchrony (Table 2). These results indicate that scarification, besides the faster germination and stabilization, also provides less time to a seed lot germinates.

Mean time to stabilize germination to scarified seeds was around four times lower than the control group (Table 1). Mean time to stabilize germination is an important index to seedling producers since it indicates the time required to reach the maximum values of germination, providing the adequate time of waiting between seeding and seedling transplant. Thus, the mean time to stabilize germination reveals the time necessary to reach the best exploitation of a seed lot. Therefore, seeds of $C$. ferruginea without treatment would take approximately 4 months do reach stabilization of germination, with a 40 days variation. While scarified seeds would take lesser time, about one month, with 15 days of variation. Borin et al. [15] found that $C$. ferruginea seeds when submitted to chemical scarification with sulfuric acid promote stabilization on 12 days after seeding. Although it is necessary to consider the different biological implications provided by those methods over tegumentar seed dormancy and the germination process. Also, it is important to notice that acid scarification can't be easily applied to a great number of seeds, it is an expensive method and there is a potential risk associated with this procedure $[3,5]$.

The first stage of germination is soaking, that occurs with water absorption. Many factors influence water penetration in seeds. The number and distribution of the pores, water availability, temperature, hydrostatic pressure, and surface area are some of them [16], and they affect directly the time required to start the germination process. The main effect associated with tegumentar dormancy is the thick tegument that limits water penetration and precludes germination [5]. Therefore, even if seeds are exposed to ideal environmental conditions, they do not germinate. The presented data suggest that scarification reduce significantly the time to a seed lot germinate, and reaches stabilization.

Germination rate is an important index to plant producers since it describes the financial feedback in the acquisition of seeds of a species. The germination rate obtained to 150 days of the study indicates that scarification promotes a significant increase of germination. Martins et al. [6] found that scarified seeds of $C$. ferruginea reach a germination rate of 53\%, a lower value than found in this study. This study data also conflicts with Lorenzi [1] information, that C. ferruginea has a low germination rate. However, the first authors used sandpaper on the scarification process and measured germination in the seventh and fourteenth days after seeding. When compared to Figure 1 curve, the results found by those authors are similar to the values obtained to the seventh and fourteenth day, expressing that the germination rate obtained by Martins et al. [6] was timerestricted but consistent with the study data.

Uncertainty index (Table 2) describe the heterogeneity of the seed germination process, hence, higher index values indicate less synchronization of germination [12]. Control treatment showed higher uncertainty index, which means lower synchrony, probably due to its low germination and almost constant rate during the analyzed period (Figure 2), when compared to scarification treatment. At the end of this study analysis, the control group exhibits an increase in germination rate. This pulse observed at $117^{\circ}$ day is consistent with spring beginning. This period presented higher temperatures and lesser thermal amplitude of the plant nursery region. Probably 
higher temperatures influenced the germination process because the temperature is an important factor that influences the velocity and uniformity of germination process [17].

Desynchronized seed germination has important ecological implications due to the creation of a proper seed bank [18]. Since seed banks are responsible for a long-term and constant provision of new individuals to some natural population, a group of seeds that presents unsynchronized germinations can properly play seed bank role. Control group germination pattern, with sporadic and lingering germination (Fig. 2), fill those characteristics and indicate that seeds from one single cohort are capable of a long-term providence of new seedlings (recruits). Scarified seeds are very different; most germinations are concentered on the seventeenth day after seeding. Afterward that period, the emergency rate quickly drops. This effect, of general germination being concentrated in a short time period, implicates in a reduced asynchronism index (Table 2), as the time required to germination is very homogeneous. A very useful effect in a seedling commercial production context, since a higher germination homogeneity implies a reduction of the required time to take care of a seed lot.

Scarification procedure focuses on wound seed tegument, making water penetration possible $[5,6]$. Thus, the results indicate that mechanical scarification of $C$. ferruginea seeds enable the soaking processes to happen in great number, what makes most of the seeds germinating at the same time.

\section{Open-field vs greenhouse production method}

The open-field production process differs mainly by the energy requirements when compared to the greenhouse process. In general, open-field crops require much less electricity and labor [19]. Although, during this study evaluation, the open field production method seemed not to be adequate. Since the germination rate was drastically affected (Fig. 3), germination was slower (Table 3) and presented reduced synchrony. In general, greenhouses promote higher and less variable temperatures, protect seedlings from intense wind, sunlight exposure and herbivores [19]. Propitiating higher germination and better seedling survival. In this study, there are no statistical differences between those methods concerning mean germination time or the uncertainty index. Besides that, this study focused on germination, during the experiments and after the analyzed period, seedling survival seems to be very different between those procedures. Thus, future studies must be aware that to evaluate those production methods death rate it is an important parameter to be analyzed since it seems to greatly differ between them.

Despite the vast sample of seeds provided some robust results, this study data must be carefully used, due to other possible factors that can influence the indexes here presented. As discussed by Martins et al. [6] C. ferruginea seeds collected from the ground and directly collected from trees presented differences on germination rates, thus our results could be different considering variations on gathering conditions. Besides vermiculite has been exhibit positive results on Fabaceae family germination $[17,18]$. The substrate type and size of the recipient can affect the germination process [19-21]. Even the experiment duration could be not long enough to properly characterize seeds in natural conditions.

\section{Conclusions}

Mechanical scarification is an effective method to overcome tegumentar dormancy of Cassia ferruginea seeds, providing a faster, synchronized and more profitable germination, features that propitiate the seedling production. Open-field seems to affect negatively many of the germination's important indexes, and indicate that this is not an adequate method for the seedling production process.

\section{Conflict of Interest}

The author declares no conflict of interest 


\section{Acknowledgments}

Secretaria do Verde e Meio Ambiente, of São Paulo due to its trainee programs, that propitiate experience and opportunities. In addition, the workgroup of Harry Blossfeld Municipal plant nursery, especially my trainee co-workers and Mr. Claudionor. My bosses Leila Borges Proença and Guilherme Brandão do Amaral for making this idea possible, which can make Brazilian's native plant production better. Also Rafaela C. Perez and Juliana de Lemos due to their consistent advising.

\section{References}

[1] H. Lorenzi, Árvores brasileiras: manual de identificação e cultivo de plantas arbóreas nativas do Brasil. Nova Odessa: Plantarum, 2002.

[2] R. H. M. de Andrade, E. C. S. de Freitas, H. N. de Paiva, and R. A. de Medeiros, "Adubação fosfatada na produção de mudas de Cassia ferruginea e Cassia Grandis," Nucleus, 15(1)(2018), pp. 41-49 doi: 10.3738/1982.2278.1792.

[3] J. A. P. Fowler and A. Bianchetti, "Dormência em sementes florestais," Embrapa Florestas, no. Documentos 40, pp. 1-27, 2000.

[4] E. H. A. Rodrigues, I. B. Aguiar, and R. Sader, "Quebra de dormência de sementes de três espécies do gênero cassia,” Rev. Bras. Sementes, 12(2) (1990)pp. 17-27.

[5] F. Popiginis, Fisiologia da semente, 2nd ed. Brasília, 1985.

[6] C. C. Martins, C. G. Machado, A. Martinelli-Seneme, and C. Zucareli, "Método de colheita e superação de dormência na qualidade fisiológica de sementes de Cassia ferruginea," Semin. Agrar., 33(2) (2012), pp. 491-498. doi: 10.5433/1679-0359.2012v33n2p491.

[7] J. A. dos Santos, L. V. A. Pinto, and A. J. Pereira, "Avaliação do desenvolvimento morfológico inicial de quatro espécies de leguminosas arbóreas sob diferentes substratos," Rev. Agrogeoambiental, 1(1) (2009), pp. 08-16.

[8] D. Ferraz, W. P. Ramalho, and L. S. R. Vale, "Methods for overcoming dormancy and seed storage of enterolobium contortisiliquum," Acta Sci. - Agron., 41(1) (2019), pp. 1-7, doi: 10.4025/actasciagron.v41i1.42602.

[9] M. C. de Oliveira et al., Manual de Viveiro e Producao de Mudas Espécies Arboreas Nativas do Cerrado. Brasília: Rede de Sementes do Cerrado, 2016.

[10] "SMA - Sistema de monitoramento agrometereológico," 2018. [Online]. Available: http://sma.fundacaoabc.org/climatologia/classificacao_climatica/sao_paulo. [Accessed: 20Oct-2018].

[11] F. J. Czabator, "Germination value: an index combining speed and completeness of pine seed germination,” For. Sci., 8(4) (1962), pp. 386-396.

[12] M. A. Ranal and D. G. de E. Santana, "How and why to measure the germination process?," Rev. Bras. Botânica, 2 (2006) pp. 1-11, doi: 10.1590/S0100-84042006000100002.

[13] L. G. Laboriau, "A germinação das sementes," Programa Regional de Desenvolvimento Científico e Tecnológico Série de Biologia, 1983.

[14] F. Lozano-Isla, O. E. Benites-Alfaro, and M. F. Pompelli, "GerminaR: An R package for germination analysis with the interactive web application 'GerminaQuant for R,"' Ecol. Res., 34(2) (2019), pp. 339-346, doi: 10.1111/1440-1703.1275.

[15] A. Borin, C. A. D. Teixeira, K. Lema, and A. R. Ramalho, "Germinação de Cassia ferruginea (Schard.) ex DC submetidas a diferentes tempos de escarificação em H2SO4," Inf. Abrates, 15(1 (2005), p. 381. 
[16] K. S. Oliveira and M. A. I. Aloufa, "Avaliação dos efeitos mecânicos e químicos na quebra de dormência de sementes de canafístula," in XII Congresso Nacional de Meio Ambiente de Poços de Caldas, 2015, p. 9.

[17] E. D. Cruz, F. de O. Martins, and J. E. U. de Carvalho, "Biometria de frutos e sementes e germinação de jatobá-curuba (Hymenaea intermedia Ducke, Leguminosae Caesalpinioideae)," Rev. Bras. Botânica, 24(2) (2001), pp. 161-165. doi: 10.1590/S010084042001000200005.

[18] A. G. de F. A. Sales, "Dormência, germinação e vigor de sementes de Parkia pendula (Willd.) Benth.ex Walpers e Samanea tubulosa (Benth.) Barneby \& Grimes," Universidade Federal Rural de Pernambuco- Forestry engeneering Department, 2009.

[19] B. Ozkan, C. Fert, and C. F. Karadeniz, "Energy and cost analysis for greenhouse and openfield grape production," Energy, 32(8) (2007), pp. 1500-1504. doi: 10.1016/j.energy.2006.09.010.

[20] L. de L. P. Regnier, "Germination analysis of Pterocarpus rohrii Vahl under different sowing techniques," Int. J. Curr. Res., 11(2) (2019), pp. 1495-1499, doi: https://doi.org/10.24941/ijcr.34394.02.2019.

[21] J. L. de S. Carvalho Filho, M. de F. Arrigoni-Blank, A. F. Blank, and M. S. A. Rangel, "Produção de mudas de jatobá (Hymenea courbaril L.) em diferentes ambientes, recipientes e composições de substratos.," CERNE, 9(1) (2003), pp. 109-118.

[22] F. C. M. Piña-Rodrigues, J. M. Freire, P. S. dos S. Leles, and T. B. Breier, Parâmetros Técnicos para a produção de Sementes Florestais, 1st ed. UFRRJ: Seropédica, 2007. 